\title{
The effect of various seed pretreatments to improve germination in eight indigenous tree species in the forests of Cameroon
}

\author{
Pierre Marie Mapongmetsem ${ }^{\mathrm{a}^{*}}$, Bahiru Duguma ${ }^{\mathrm{b}, \mathrm{c}}$, \\ Bernard Aloys Nkongmeneck ${ }^{\mathrm{d}}$, Eric Selegny ${ }^{\mathrm{e}}$ \\ ${ }^{a}$ University of Ngaoundere, Faculty of Science, PO Box 454, Ngaoundere, Cameroon \\ ${ }^{b}$ IRAD / ICRAF Project, PO Box 2067, Yaounde, Cameroon \\ c 3125 Eccles, Appartment $n^{\circ}$ Ogden, UI 84403, USA \\ ${ }^{\mathrm{d}}$ University of Yaounde I, Faculty of Science, PO Box 812, Yaounde, Cameroon \\ ${ }^{\mathrm{e}}$ University of Rouen, PO Box 76821, Saint-Agnan, France
}

(Received 28 December 1998; accepted 12 April 1999)

\begin{abstract}
Techniques were tested for improving germination in eight tree species indigenous to Cameroon forests. Manual scarification was the most efficient treatment for all species, although a significant interaction between treatment and species was found. Only one species was sensitive to all treatments. The use of sulphuric acid was not an effective alternative to manual scarification. (C) 1999 Inra/Éditions scientifiques et médicales Elsevier SAS.
\end{abstract}

scarification / boiling water / sulphuric acid / sowing depth

Resumé - Effet de divers prétraitements sur l'amélioration de la germination de huit essences locales des forêts camerounaises. Des études ont été menées sur la germination de huit essences agroforestières indigènes des forêts camerounaises. La scarification manuelle était le meilleur traitement pour toutes les espèces, bien qu'il existait une interaction significative entre traitement et espèce. Une seule espèce a été sensible à tous les traitements. L'utilisation de l'acide sulfurique n'a pas été une alternative effective à la scarification manuelle. (C) 1999 Inra/Éditions scientifiques et médicales Elsevier SAS.

scarification / eau bouillante / acide sulfurique / profondeur de semis

\section{Introduction}

Rapid population growth and demands for increases in land production, especially from agriculture, have led to a rapid disappearance of tropical rain forests and to land scarcity for peasant farmers [11]. As a result, the traditional fallowing system is disintegrating. Fallow periods are being shortened and cropping periods lengthened. This leads to declining soil fertility, falling yields and a serious problem of weed invasion into cropland. These substantial constraints reveal the need to introduce a land use system which can allow the farm-

\footnotetext{
* Correspondence and reprints
}

Fax: 252520 or 251415 
ers to save the forest while sustaining agricultural production. Some agroforestry technologies (alley farming, fodder banks, simple improved fallow, home gardens, live fences) have been developed with the objective to improve soil fertility and reduce the fallow period through the use of nitrogen fixing trees and prunings [7]. Most agroforesry trees used in the development of the novel technologies are exotic (Cajanus cajan, Sesbania sesban, Crotalaria anagyroides, Calliandra callothyrsus) and are not well known by the farmers. However, there are several local varieties of agroforestry trees including Alstonia boonei.De Wild., Ceiba pentandra (L.) Gearth., Cordia platythyrsa Bark., Milicia excelsa (Welw.) c.c Berg., Pycnanthus angolense (Welw.) Warb., Ricinodendron heudelotii (Baill.) Pierre ex Pax., Terminalia superba Eng1. \& Diels. and Triplochiton scleroxylon $\mathrm{K}$. Schum, all of which are well known locally as sources of food, fodder timber and medicine, but their potential as substitutes for the exotics has not been investigated $[17,18]$. Even less is known about propagating them from seeds, creating a serious constraint for use in the new agroforestry technologies. Preliminary studies have shown that they have generally poor germination [15]. There are two factors which influence the dormancy degree of the seed: 1 ) the relative maturity of the seed and 2) the humidity level during maturation $[12,13]$. The author suggests also that the dormancy level is higher in drier environments. All the influences which occur before the dispersion are 'maternal environment' [22].

The present study aimed at identifying easily applied pretreatments that can be used to treat large quantities of seeds to assure fast, homogeneous and synchronised germination. One specific objective was to overcome the dormancy of Ricinodendron heudelotii. The underling hypothesis is that there could be a polymorphism of the germination behaviour of the seeds depending on the presowing techniques applied.

\section{Materials and methods}

\subsection{Description of location}

The study site is located in humid lowlands of Cameroon (situated: latitude $2^{\circ} 56^{\prime} \mathrm{N}-3^{\circ} 52^{\prime} \mathrm{N}$; longitude $11^{\circ} 32^{\prime} \mathrm{E}-11^{\circ} 57^{\prime} \mathrm{E}$; altitude $813 \mathrm{~m}$ ). According to data collected between 1980 and 1992, mean annual rainfall is $1269 \mathrm{~mm}$ usually distributed in two rainy seasons with a distinct dry period, although rainfall pattern varies from year to year. The average temperature is $23.4{ }^{\circ} \mathrm{C}$; while relative humidity averages $75.1 \%$. Ferralitic soils predominate. Fallowing is the most commonly used technique for ameliorating soil fertility on farming land, the main crops being cassava, groundnut and maize. Poultry, pigs and small ruminants are the major domestic source of animal protein in the region [8].

\subsection{Selection of species}

An earlier ethnobotanical survey carried out in the area [8] showed that local farmers had good knowledge of indigenous agroforestry species, the ten most promising being Ceiba pentandra $(70 \%=$ interviews in which the species was mentioned), Terminalia superba (57\%), Triplochiton scleroxylon (56\%), Cordia platythyrsa (24\%), Milicia excelsa (24\%), Pycnanthus angolense (24\%), Alstonia boonei (18\%), Ricinodendron heudelotii (18\%), Ficus exasperata (12\%) and Ficus mucuso $(10.5 \%)$. In the present paper the two Ficus species were excluded.

\subsection{Seeds collection, processing and handling}

Seeds for all species were collected in 1992. Mature and healthy seeds for each species used in different trials were from four seed bearers. After harvesting, they were mixed in view of minimising inter genetic variations. They were screened and handled differently according to their morphological structures. In $T$. superba, $T$. sclerox$y$ lon, the wings of the seeds were removed. Concerning $A$. boonei and $C$. pentandra, the hair and cotton were removed, respectively, before drying. For $M$. excelsa, fruits were crushed by hand in a container with water, fertile seeds falling to the bottom. They were extracted and washed several times with water from the cold supply. As far as $R$. heudelotii is concerned, the seeds were left for about 2 weeks to enable disintegration of the mesocarp after which they were crushed in a container as above. The seeds were washed many times and dried for about 4 weeks. The seeds of $C$. platythyrsa and $P$. angolense were collected, extracted and dirt removed, then pretreated and sown immediately because they are refractory. The seeds of the species which did not fall into this category were dried in the open for 2-4 weeks, after which they were weighed and put in sealed sample bags from International Board of Plant Genetic Resources (IBPGR), put in large, dark polythene bags and conserved in the freezer $\left(20-25^{\circ} \mathrm{C}\right)$ pending the sowing period.

\subsection{Methodology}

Seeds were germinated in petri dishes lined with filter paper sprayed with $25 \mathrm{~mL}$ of water. Ambient temperature in the laboratory varied from 25 to $30^{\circ} \mathrm{C}$. 
The treatments used were: 1) seeds soaked for $12 \mathrm{~h}$ in water from the cold supply; 2) seeds soaked for $3 \mathrm{~min}$ in boiling water; 3 ) seeds soaked in approximately $0.5 \mathrm{~L}$ of $98 \%$ sulphuric acid (just enough to cover the seeds) for $20 \mathrm{~min}$, and stirred every $3 \mathrm{~min}$; 4) seeds hand scarified by puncturing the seedcoats at both the micropyle and the opposite end; and 5) untreated seeds (control). A splitplot experimental design with four replications was employed. The main components were species, with subcomponents represented by the various treatments.

In a second germination trial carried out on $R$. heudelotii, seeds were soaked in sulphuric acid $(98 \%)$ at different times: $20,35,45,60,75,90$ and $180 \mathrm{~min}$. The experimental design was a randomised complete block with four replications.

To determine the effect of alternating hot and cold water immersions on the germination of $R$. heudelotii, seeds were soaked as follows: 1$)$ cold $\left(0{ }^{\circ} \mathrm{C}\right)$ water for $12 \mathrm{~h} ; 2)$ boiling $\left(100^{\circ} \mathrm{C}\right)$ water for $\left.3 \mathrm{~min} ; 3\right)$ cold $\left(0{ }^{\circ} \mathrm{C}\right)$ water for $12 \mathrm{~h}$ followed by boiling water for $3 \mathrm{~min}(0$, $100{ }^{\circ} \mathrm{C}$ ); 4) boiling water for $3 \mathrm{~min}$ followed by cold water for $\left.12 \mathrm{~h}\left(100,0^{\circ} \mathrm{C}\right) ; 5\right)$ cold water for $12 \mathrm{~min}$ followed by boiling water for 3 min followed by cold water for $\left.12 \mathrm{~h}\left(0,100,0{ }^{\circ} \mathrm{C}\right) ; 6\right)$ boiling water for $3 \mathrm{~min}$ followed by cold water for $12 \mathrm{~h}$ followed by boiling water for $3 \mathrm{~min}\left(100,0,100{ }^{\circ} \mathrm{C}\right)$; and 7) no treatment (control). Four replications were tested in a completely randomised block design.

Concerning the test of the effect of sowing depth on germination of $R$. heudelotii, seeds were sown in a polyethylene bag containing a soil/sand (70/30) mixture at 0 ,
$2.5,5$ and $10 \mathrm{~cm}$. This experiment was set up as a randomised complete block design with four replications.

For each of the above-mentioned experiments, the experimental unit was made up of 60 seeds. The first two experiments were carried out in the open laboratory under ambient conditions, whereas the third was undertaken in the nursery ambient conditions. The seed was considered germinated if the radicle goes through the seedcoat in the first two experiments and when the seedling appears above the substrate for the third one. Data were collected at 3-day intervals. The germination duration ranged from 2 to 9 weeks.

The number of seeds germinated were counted and the percentage germination computed. Variance and correlations were calculated using the statistical package Bstat. Means were compared using Duncan's multiple range test [10].

\section{Results}

Highly significant $(P<0.001)$ differences were found among species and among pretreatments, resulting in a highly significant species $\times$ treatment interaction. Germination ranged from $0 \%$ in $A$. boonei seeds treated with boiling water to $100 \%$ in those of $C$. platythyrsa, $M$. excelsa, $P$. angolense and $T$. superba that had been hand scarified (table I). The overall mean germination for hand scarification was over $85 \%$, indicating that this was the most efficient treatment. Whereas seeds of most species responded well to only one or two treatments, seeds of $C$. pentandra were sensitive to all treatments. Boiling water

Table I. Effect of five pretreatments on percentage germination of Alstonia boonei (AB), Ceiba pentandra (CE), Cordia platythyrsa (CO), Milicia excelsa (ME), Pycnanthus angolense (PA), Ricinodendron heudelotii (RH), Terminalia superba (TE) and Triplochiton scleroxvlon (TR).

\begin{tabular}{|c|c|c|c|c|c|c|}
\hline \multirow[b]{2}{*}{ Species } & \multirow[b]{2}{*}{ Control } & \multicolumn{3}{|c|}{ Germination ( $\%$ ) } & \multirow[b]{2}{*}{$\mathrm{H}_{2} \mathrm{SO}_{4} 98 \%$} & \multirow[b]{2}{*}{ Means } \\
\hline & & Hot water & Ordinary water & Hand scarification & & \\
\hline $\mathrm{CE}$ & 49 & 59.5 & 56.6 & 68.5 & 77.5 & 62.22 \\
\hline $\mathrm{CO}$ & 61 & 0.5 & 1.5 & 100 & 55.50 & 43.70 \\
\hline ME & 64.6 & 2.5 & 91.00 & 100 & 0.00 & 51.62 \\
\hline $\mathrm{TE}$ & 61.3 & 0 & 71.70 & 100 & 63.70 & 59.34 \\
\hline TR & 6 & 0 & 5.0 & 69.0 & 2.0 & 16.40 \\
\hline Means & 47.23 & 8.19 & 25.25 & 85.21 & 42.98 & 41.78 \\
\hline
\end{tabular}

LSD.05 between species: 10.01 ; between treatments: 5.15 .

$\mathrm{CV} \%$ between species: 23.94; between treatments: 12.33 . 
killed most if not all the seeds of $A$. boonei, $C$. platythyrsa, T. superba and T. scleroxylon, but not those of $C$. pentandra, $M$. excelsa, $P$. angolense and $R$. heudelotii, while sulphuric acid killed the seeds of $A$. boonei, $M$. excelsa and $P$. angolense (table I). Similar results with sulphuric acid have been reported for Casuarina equisetifolia even after a 5-min immersion [9]. However, $77.5 \%$ of $C$. platythyrsa seeds germinated and almost $64 \%$ of $T$. superba when soaked in acid for 20 min (table I). Cold water alone had very little effect on seeds of C. platythyr$s a$ and $R$. heudelotii but had varying effects on the other species. This wide variation in responses to the treatments indicates considerable differences among species in the structure of the seedcoat as protective barrier. Hand scarification produced $100 \%$ germination in seeds of four species, demonstrating that once the seedcoat had been scarified, that is, punctured at both ends, water and oxygen were able to move into the seed tissues and stimule blastogeny. The entry of water modifies the physiological status of the seed [2]. Puncturing at the micropyle is probably significant because the radicle then encounters least resistance to its elongation.

The effectiveness of hand scarification in enhancing germination in the species studied here is supported by observations on Terminalia ivorensis [1], Leucaena leucocephala [6], Myrica faya [14], Tetrapleura tetraptera $[19,20]$, Ricinodendron heudelotii [16], Vitellaria paradoxa and Lophira lanceolata [18] and Canarium schweinfurthii [21]. In this study hand scarification significantly increased germination rate in all species. Although sulphuric acid had been recommended as one of the best treatments to overcome seed dormancy in some species [6], the results from the first experiment did not confirm this for $R$. heudelotii seeds. This may have been due to the soaking time being too short. In a second experiment the soaking time in sulphuric acid was increased up to 180 min, resulting in germination from $0 \%$ for soaking duration longer than $60 \mathrm{~min}$, to $15 \%$ (maximum) after soaking for $60 \mathrm{~min}$ (table II). Despite the differences being statistically significant $(P<0.05)$, germination after soaking in sulphuric acid was inferior to that obtained by hand scarification. Soaking time in acid was not significantly related to germination $(\mathrm{dl}=6, \mathrm{r}=-0.24, P>0.05)$, which contrasts with the effects on $L$. leucocephala in which germination increased with longer treatment duration up to $60 \mathrm{~min}$; the seedcoats of the Euphorbiaceae $(R$. heudelotii) is tougher than that of the Leguminoseae (L. leucocephala).

When seeds of $R$. heudelotii were subjected to various pretreatment combinations of hot and cold water, no clear trend in germination was found (figure 1). No significant differences between treatments occurred during the first 3 weeks after planting, but differences became significant after the 4th week. Exposing the seeds to a 12 -h soak in cold water $\left(0{ }^{\circ} \mathrm{C}\right)$ followed by a 3-min soak in boiling $\left(100^{\circ} \mathrm{C}\right)$ water gave the best germination, approximately $65 \%$. Other combinations of hot and cold water treatments gave less than $50 \%$ germination 2 months after planting. Changing the water temperature creates a mechanical shock which causes a change in the seedcoat, thereby facilitating the incursion of water and oxygen indispensable for germination [3].

It was observed that many seeds died indicating that cold or hot water had made contact with the embryos. This occurred because the seedcoats, which normally regulate the uptake of water, had been damaged and the rapid increase in water caused irreversible damage.

Germination of $R$. heudelotii seeds increased as sowing depth increased (figure 2). Best germination, $60 \%$, occurred at $10 \mathrm{~cm}$, which is contrary to the results for Metrosideros polymorpha in which germination decreased with increasing depth [5]. Our study did not, however, investigate sowing depths beyond $10 \mathrm{~cm}$.

\section{Discussion}

Our results demonstrate that each species has its own characteristic set of germination requirements with a particular threshold of response according to its peculiar degree of heterochrony: the most heterochronic species, the seeds of which are subjected the most to environmental variations during their development, will present the highest plasticity response. It appears that hand scarification significantly improved germination in all species. $C$. pentandra was sensitive to all treatments while $R$. heudelotii responded to only a few treatments. Hand scarification could be regarded as a feasible alternative to sulphuric acid treatment. However, the quantity and the size

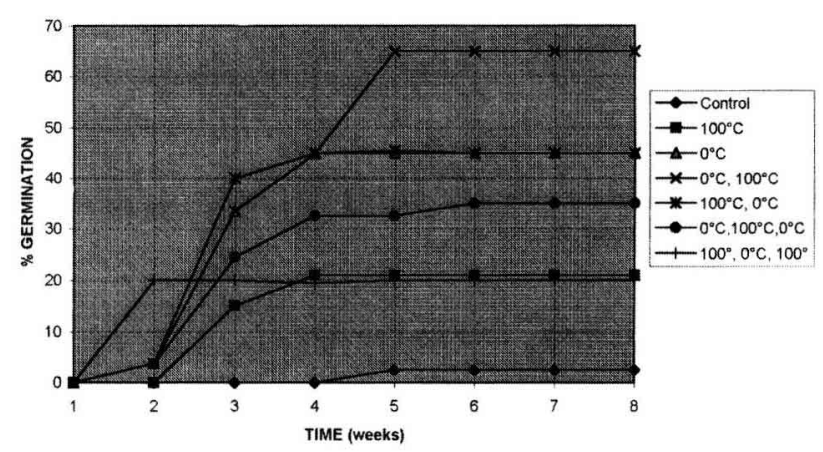

Figure 1. Effect of hot and cold water soaks on the germination of Ricinodendron heudelotii. 
Table II. Effect of soaking time in sulphuric acid on germination percentage of Ricinodendron heudelotii.

\begin{tabular}{lc}
\hline Time $(\min )$ & Germination $(\%)$ \\
\hline 20 & 1.67 \\
35 & 1.67 \\
45 & 1.67 \\
60 & 15.00 \\
75 & 0 \\
90 & 0 \\
180 & 0 \\
Mean & 3.57 \\
LSD.05 & 4.95 \\
CV \% & 47.00
\end{tabular}

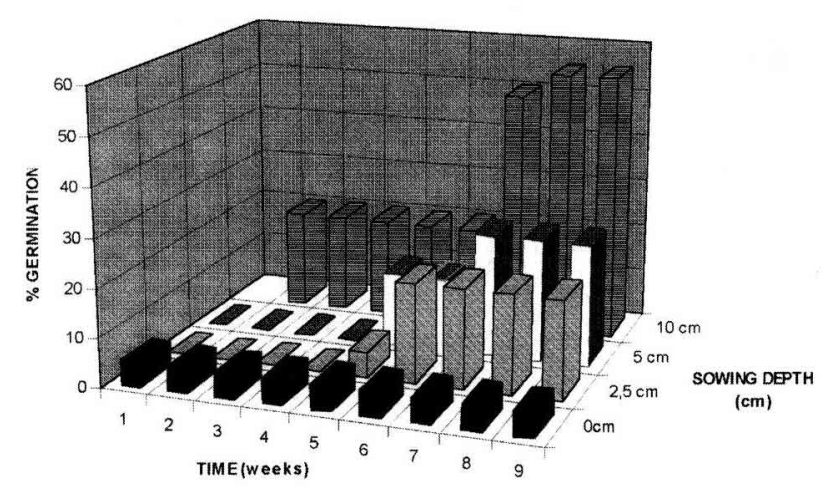

Figure 2. Effect of sowing depth on germination of Ricinodendron heudelotii sceds.

of the seed can be a constraint. More research is required to improve the efficiency of this approach. It should be based on the effects on germination of seed maturity, seed position on the branch and position of the branch.

Acknowledgements: Our thanks to the International Centre for Research in Agroforestry (ICRAF) which provided funds and assisted us in many other ways for the work described here. Dr M.C. Lawren and D. Parker of the biometric Unit of the Institute of Agronomy Research gave much help in statistical problems. The authors are also indebted to two anonymous reviewers who edited the manuscript.

\section{References}

[1] Bibani Mbarga, Germination du Framiré, Mémoire. Ing. Eaux et Forêts, ENSA. Nkolbisson, Cameroun, 1983.
[2] Chadœuf-Hannel R., Barrelis G., Influence de différents régimes hydriques sur la croissance végétative, le poids et la germination des graines d'une mauvaise herbe cultivée en serre Amaranthus retroflexus L., Rev. Agron. 9 (1982) 279-302. 1970 .

[3] Côme D., Les obstacles de la germination, Masson, Paris,

[4] Dialla I., Danthu P., Sambou B., Dibor D., Goudiaby A., Poulsen K., Effects of different pretreatments on the germination of Faidherbia albida (Del.) A. Chev. seeds, Int. Tree Crops J 9 (1996) 31-36.

[5] Donald Drake R., Germination requirements of Metrosideros polymorpha, the dominant tree of Hawaii in lava flows and rain forests. Hawaii, USA, Biotropica 27 (4) (1993) $461-467$.

[6] Duguma B., Study of factors affecting establishment of selected tree species of potential importance in Agroforestry, Ph.D. thesis, Ibadan, Nigeria, 1985.

[7] Duguma B., Mollet M., Provenance evaluation of the Calliandra calothyrsus Meissner in the humid lowlands of Cameroon, Agrofor. Syst. 37 (1997) 45-57.

[8] Duguma B., Tonye J., Depommier D., Diagnostic survey on local multipurpose tree shrubs, fallows systems and livestock in South Cameroon, Working paper 60, 1990

[9] Eze J.M.O., Ahonsi M.O., Improved germination of the seeds of whistling pine (Casuarina equisetifolia) Forst and Forst (Casuarinaceae) by various presowing treatments, Agronomie 13 (1993) 889-894.

[10] Finney D.J., An Introduction to Statistical Science in Agriculture, 4th ed., Monksgaard, 1972.

[11] Floquet A., Conservation of soil fertility by peasant farmers in Atlantic Province, Benin, in: Kotschi J. (Ed.), Ecofarming Practices for Tropical Smallholdings. Tropical Agroecology 5, Weikershein, Germany, 1990, pp. 29-53.

[12] Karssen C.M., Environmental conditions and endogenous mechanisms involved in secondary dormancy of seeds, Isr. J. Botany 29 (1981) 45-64.

[13] Karssen C. M., Patterns of change in dormancy during burial of seeds in soil, Isr. J. Bot. 29 (1981) 65-73.

[14] Lawrence R., Walker, Germination of an East African invading trees species (Myrica faya) in Hawaii, USA, Biotropica 22 (2) (1990) 140-147.

[15] Mapongmetsem P.M., Phénologie et modes de propagation de quelques essences locales à potentiel agroforestier en zone forestière, thèse, Univ. Yaoundé I, Cameroun, 1994.

[16] Mapongmetsem P.M., Duguma B., Nkongmeneck B. A., Domestication of Ricinodendron heudelotii in humid lowlands of Cameroon, in: Kapseu C., Kayem G.J., (Eds.), Proc. 2nd Int. workshop on African pear (Dacryodes edulis) improvement and other new sources of vegetable oils, Ngaoundere, Cameroon, 1997, pp. 25-34.

[17] Mapongmetsem P.M., Duguma B., Nkongmeneck B.A., Selegny E., Phénologie de quelques essences à usages multiples de la zone forestière, in: Duguma B., Mallet B. (Eds.), Actes Symp. Int. Recherche et Développement en Agroforesterie en zone forestière de l'Afrique Centrale et de l'Ouest. Yaoundé, Cameroun, 1995, pp. 69-80. 
[18] Mapongmetsem P.M., Tchiengang-Megueni C., Akagou Zedong H. C., Nyomo et Laissou Moussou, Inventaire et essai de domestication de quelques oléagineux locaux du Cameroun, in: Kapseu C., Kayem G.J., (Eds.), Actes 2nd Séminaire International sur l'amélioration du Safoutier (Dacryodes edulis) et autres oléagineux non conventionnels, Ngaoundere, Cameroun, 1997, pp. 13-24.

[19] Mbolo, Germination et croissance des essences forestières du Sud-Cameroun. Exemple de quelques Légumineuses et Sapotacées, thèse, Univ. Yaoundé I, Cameroun. 1990.
[20] Ndemmeze A.R.A., Germination in vitro et croissance en pépinière de Tetrapleura tetraptera (Schum and Thonn), influence de la position de la graine dans la gousse, du poids et de la scarification, mémoire, Univ, Yaoundé I, Cameroun. 1992.

[21] Njoukam P., Germination et croissance de l'Aiélé (Canarium schweinfurthii), in: Kapseu C., Kayem G.J. (Eds.), Actes 2nd Séminaire International sur l'amélioration du Safoutier (Dacryodes edulis) et autres oléagineux non conventionnels, Ngaoundere, Cameroun, 1997, pp. 45-54.

[22] Roach D., Wulff R.D., Maternal effects in plants, Annu. Rev. Ecol. Syst. 18 (1987) 209-235. 